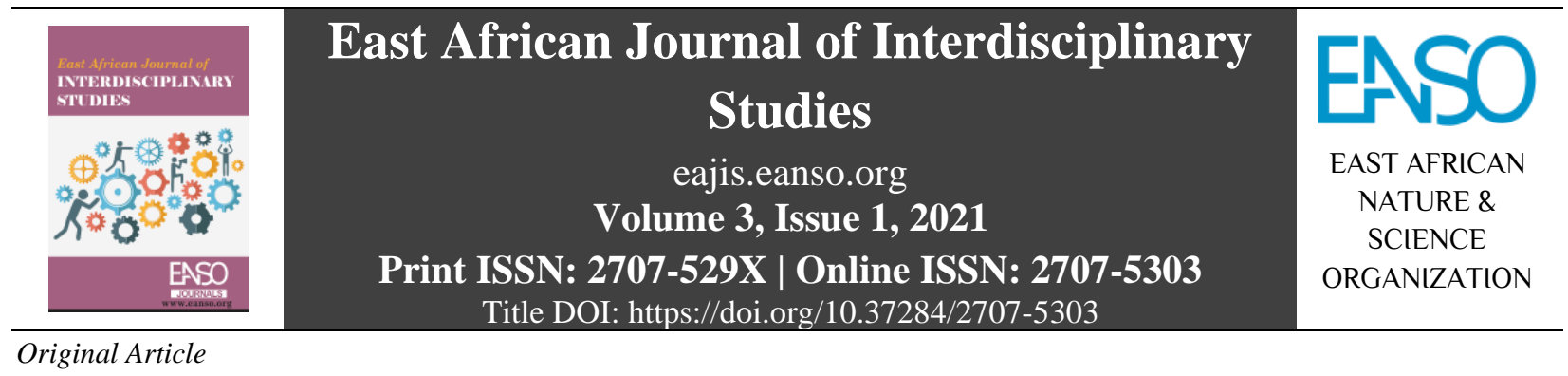

\title{
Evaluation of Occurrence of Crime Rates in Kenya within the Years 2014-2020
}

\section{Dr John Ndikaru wa Teresia, PhD}

${ }^{1}$ The Technical University of Kenya, P. O. Box 57173 - 00200, Nairobi, Kenya.

* Author Correspondence Email: jndikaru@gmail.com.

Article DOI: https://doi.org/10.37284/eajis.3.1.387

\section{Date Published: ABSTRACT}

17 August 2021 Controlling crime continues to be a big problem probably because crimes are on the increase and there is little probability for a drop in crime rates anytime in the near

Keywords: future. Kenya has shown a marked increase in the contemporary years in the occurrences of lawbreaking and violations. The rate is alarming and has attained an epidemic proportion in Kenya that everyone has gradually become not only

Cognitive, concerned but also worried. It is evident in the empirical data, audio-visual Victimization, electronic, newspapers, and print media which highlight criminal activities in

Offender, numerous parts of the country, most of which are stated to have happened in big

Crime, towns. United Nations surveys in Kenya have revealed that over half of the

Epidemic, inhabitants worry about crime constantly. Roughly $75 \%$ feel unsafe while at home.

Stigmatization Notwithstanding these continuous reports of criminal actions, the problem of crime Stigmatization, continues, in effect escalates and fewer crimes are stated. Only up to $45 \%$ of urban Functionalism, crimes are normally informed. When crimes are not reported to the police, victims Criminal, may not be able to get necessary services to cope with the persecution, offenders Homicide. may go scot-free, and law implementation and community resources may be misdirected due to a lack of precise information about local crime complications. Accepting the characteristics of crimes unknown to police, victims who do not report crimes, and the reasons these crimes are not reported may help identify gaps in the provision of criminal justice services and inform police practice and policies. Common motivations for reporting a crime include punishing the offender a lesson and discouraging other offenders.

\section{APA CITATION}

wa Teresia, J. N. (2021). Evaluation of Occurrence of Crime Rates in Kenya within the Years 2014-2020 East African Journal of Interdisciplinary Studies, 3(1), 172-185. https://doi.org/10.37284/eajis.3.1.387.

\section{CHICAGO CITATION}

wa Teresia, John Ndikaru. 2021. "Evaluation of Occurrence of Crime Rates in Kenya within the Years 2014-2020". East African Journal of Interdisciplinary Studies 3 (1), 172-185. https://doi.org/10.37284/eajis.3.1. 387.

\section{HARVARD CITATION}

wa Teresia, J. N. (2021) "Evaluation of Occurrence of Crime Rates in Kenya within the Years 2014-2020", East African Journal of Interdisciplinary Studies, 3(1), pp. 172-185. doi: 10.37284/eajis.3.1. 387.

172 | This work is licensed under a Creative Commons Attribution 4.0 International License. 


\section{IEEE CITATION}

J. N. wa Teresia, "Evaluation of Occurrence of Crime Rates in Kenya within the Years 2014-2020", EAJIS, vol. 3, no. 1, pp. 172-185, Aug. 2021.

\section{MLA CITATION}

wa Teresia, John Ndikaru. "Evaluation of Occurrence of Crime Rates in Kenya within the Years 2014-2020". East African Journal of Interdisciplinary Studies, Vol. 3, no. 1, Aug. 2021, pp. 172-185, doi:10.37284/eajis.3.1. 387.

\section{INTRODUCTION}

One of the major roles of government is to curb crime. To achieve this, the government relies on the members of the public to cooperate by reporting criminal activities or their victimization. In this regard, a victim's choice to report victimization to the police is very significant. Reporting crime to the police is well-defined as the act of informing the police of a crime that took place. In most cases, crime reporting takes place at a police station. However, this does not rule out the option to notify the police by telephone, and nowadays as technology advances, one can report small crimes through the website. There are calls for free lines in which one can reach the police. Notwithstanding all this, a lot of criminal victimization is not conveyed to the police and, consequently, many offenders will never be known and sued. For example, only half of all incidents of six types of crime in 17 industrialized countries are reported to the police (Bouten, Goudriaan, and Nieuwbeerta, 2002). Therefore, it is important to understand the conditions under which victims report (or do not report) for the development and implementation of crime control strategies.

When and why crime victims (do not) report their victimization to the police has been the subject of empirical criminological research since the seventies. In many victimization surveys, victims are asked in retrospect about their motivations to report or not report certain crimes. For those who say that they have reported their victimization to the police, they are asked why they have done so, and those who say they have not reported their victimization are asked why they have not. Tanner in his book "Crime in East Africa" has highlighted several reasons why people would choose not to report the crime. One of the reasons highlighted is 'The convenience of the public' in terms of distance to the police station, which determines the rate of reporting. If the stations are far from the place of crime, most people will forego reporting to avoid unnecessary costs.

\section{EMPIRICAL LITERATURE}

Trust in the police is a critical factor determining whether victims will report to the police about their victimization. According to Boateng (2016), one of the key factors that influence victims to report crime is their attitude towards the police. Gutierrez and Kirk (2017) concur that victims who trust the police system are highly likely to report criminal activities as compared to those who distrust the police.

Victims are also influenced by the gains that they may get from reporting the crime. Boateng (2016) established that victims assess the costs and benefits of reporting a crime to the police, a decision that is associated with the rational choice theory. In the sense that if the victims find that reporting will be beneficial in comparison to the associated costs, then they will be more willing to report to the police. If victims think that reporting will be costlier than beneficial, they will not report the crime to the police. They, therefore, make a rational assessment of the criminal event before they decide to report to the police. The costs related to reporting a crime to the police could be associated with the possibility of retaliation by the offender, shame and embarrassment and stigmatization from the public and the challenges associated with the judicial trial processes. The benefits related to reporting crime may include receiving protection from the authorities, preventing future victimizations by the offender (s) and receiving treatment from the appropriate agencies.

Victims of criminal activities need to be sure that the information they share with the police will be kept confidential and that the police will handle their address fairly and efficiently; end that they will not be subject to further victimization by the system (van de Weijer, Leukfeldt, and Zee, 2020). Psychological factors also contribute to whether

173 | This work is licensed under a Creative Commons Attribution 4.0 International License. 
victims of crime will report it to the police. Victims who are ashamed of their victimizations may opt not to report the crime to police while those who seek retribution are highly likely to report the crime so that they can get the perpetrators to book (LeitgöbGuzy and Hirtenlehner, 2015). The victim may be dissuaded from reporting in case they have a relationship with the offender which may cloud their judgment and make them empathetic with the offender. Their decision not to report the crime, in this case, is informed by their preference to avoid negative consequences for the offender (van de Weijer, Leukfeldt, and Zee, 2020).

There are also demographic factors that influence the reportage of crime among the members of society. In most instances, older victims are highly likely to report a crime to the police as compared to younger victims (Leitgöb-Guzy and Hirtenlehner, 2015). Besides, women are also highly likely to report their victimization as compared to their male counterparts (Baumer and Lauritsen, 2010). Additionally, married victims are more likely to report their offending partners than those who do not have a partner (van de Weijer, Leukfeldt, and Zee, 2020).

\section{THEORETICAL FRAMEWORK}

Several theories have been studied to enhance the understanding of criminalization. Such theories include functionalism, rational choice theory, and cognitive theory of motivation.

\section{Functionalism Theory}

Functionalism observes society as a system that is a set of consistent parts which together result in a whole. The basic unit of analysis is society, and its numerous parts are understood principally in terms of their association to the whole. Emile Durkheim (1938) stated that society has a certainty of its own over and above the persons who comprise it. Members of the society are forced by 'social facts' byways of substitute, feeling and thinking, external to the individual and gifted with power and coercion, by the aim of which they govern him. Beliefs, as well as moral codes, are approved from one generation to the next and also shared by the persons who make up the society. From this view of the idea, it is not the awareness of the individuals that guide conduct but common beliefs and opinions that transcend the individual and change his/her perception. If a society is extremely stratified and has behaviours of fighting crime, this will ride across the full society.

Durkheim was aware of the option that societies might not function easily especially in those highly developed societies. If this happens and conceit or anomie comes in, uniqueness comes as a result where actions such as reporting will be solved independently. According to English philosopher Thomas Hobbes, humankind is directed by reason and passion. Its passions, that is the main driving force, the aim of being employed to plan ways and means of providing for their fulfilment. If people's passions were not measured, they would use any means at their removal, including force and deception, to satisfy them. Nonetheless, for fear of magnitudes of 'the war of all against all', individuals agree to confine those passions and give up their freedom and enter into a social agreement with their associates.

Crime is also seen as a function of society according to the theory. Society cannot do without crime. The sociologists contend that if society was so faultless then it would failure therefore it needs effects such as crime that will lead to the formation of laws and limitations that keep the society in patterned as Black, a sociologist explained trait sociologically. According to him, he takes up reporting of crime to the police is a role of social configurations in the society in which the target and offender live (Black, 1976). It is a macro-level clarification for crime press and in general, tries to explain reporting conduct at a higher level of combination. He approved a study, which he called "The Behavior of Law", where the law is distinct as a governmental social mechanism. Examples of the behaviour of law are: how the police treat victims, offenders, and witnesses, or the belief of an offender and fatalities reporting victimization to the police. According to Black (1976), there are five social operational variables that envisage variations in the conduct of law: social stratification, culture, morphology, organization, and social control. For example, Black recommends that in people with a high point of stratification, the law is cast off more frequently, and thus additional crimes are stated to the police. 


\section{Rational Choice Theory}

Rational choice theory accepts utilitarian confidence that man is a cognitive actor who weighs means and ends, benefits and costs, and makes a balanced choice. This theory states that all an individual does particularly behaviors connected to crime are inspired by the costs and profits involved such things as money, sex, status, and excitement and that meeting these needs involves making choices.

This theory is based on the hypothesis of selfishness that is making conclusions or choices as an individual, self-interest, and maximization of goals that is the individual is thinking about him/herself and how to improve their personal objectives. Central opinions of the theory are designated as follows: The human being is a balanced actor and rationality includes end/means calculations where people easily choose the behavior, both compatible and deviant, founded on their rational controls. The central element of control involves cost-benefit analysis: Desire versus pain calculus. Choice, with all other circumstances equal, will be focused on the expansion of individual pleasure. It is therefore in agreement with this theory that the decision to report or fail to report crime is based on a costbenefit calculation by the victim determining if it is worth the effort to contact police (Skogan, 1984). The victim will not account to the police if the expected costs of reporting are advanced than the expected aids. There is also a direct association between the expanse to the police station and the cost of all supposed crimes in terms of prestige or money. (Tanner, 1970). According to this model of choice-making, crimes resulting in little or no financial harms or physical wound will be told less often, as reporting normally brings business costs, while the likely benefits of reporting are low such that police will not take the situation very seriously, or will put less effort into answering the case. Certainly, the police do not do anything at all, there will not be much advantage for the fatality as compensation and manipulating the decision of the target to report. The perceived seriousness will strongly be related to the sum of financial loss or physical injury. This is in accordance to the existing empirical research (Bennett and Wiegand, 1994; Felson, Messner, Hoskin, and Deane, 2002; Fishman, 1979; Gottfredson and Hindelang, 1979;
Kury, Teske, and Würger, 1999; Pino and Meier, 1999; Skogan, 1984; Sparks, Genn, and Dodd, 1977). However, this theory does not answer everything so the need for another theory.

\section{Cognitive Theory}

The cognitive theory of motivation seeks to explain human behavior as a product of the careful study and active processing and interpretation of information received. It works under the assumption that people's expectations guide their behavior, usually in ways that would bring about desirable outcomes. The actions of humans, in addition to what motivates them to engage in particular actions, are therefore the product of deliberate thought processes such as beliefs, expectations, and knowledge about things and past experiences. The cognitive theory of motivation is rooted in two basic factors. The first involves information available to the individual. Initially, an individual will process a situation based on whatever input is immediately available to his senses. The send factor involves the individual's past experience, which the person refers to when trying to make sense of information presently available and in determining how to respond or relate to the current situation.

Deci, Koestner and Ryan (1999) explained two types of motivations. The first is intrinsic motivation, which is the force that compels a person to fulfill his/ her inner potential and interests. This kind of motivation corresponds to the inherent desire of an individual to express his/her authentic self through selected actions and behavior, across different settings. It is said to be quite effective as people who are intrinsically motivated feel that they can influence and determine the outcomes of their efforts. This in this case would be a person reporting a crime to the police because they feel it is the right thing to do. The second motivation is extrinsic motivation which is experienced when a person's actions are influenced by the desire to attain goal objectives or rewards. In this case, a victim reports a crime in the hope of getting a reward such as recovering lost property.

\section{METHODOLOGY}

This study used available statistics on national police service annual report statistics. This cross- 
sectional study captured various categories of criminal activities in Kenya ranging from homicide, offences against morality and persons, robbery, vehicles and other thefts, and dangerous drugs. The use of data by the National Police Service was considered more reliable as compared to using data from other sources such as newspaper reports and opinion polls that are subject to bias.

This study used available statistics on national police service annual report statistics. Crossnational research on crime against humanity is focused on a large scale capturing various crimes ranging from homicide, offences against morality and against persons, robbery, vehicles and other thefts, and dangerous drugs. Comparable data has been difficult to obtain yet the police service has had an opportunity to come up with one. Previous research had utilized other sources from the remote areas as well as generated from other sources like opinion polls data as well as self-report victimization data. Several problems exist in using such reports data for comparative research. To combat the problems associated with other sources of data, Tseloni et al. (2004) suggest employment of a survey report from a government body, which has authority within their research. This approach is also problematic, as country-specific surveys are likely to have different research designs and fieldwork operations (Block, 1993). In the current study, the researcher utilized the Kenya police service annual report Survey done for the two years. These surveys report addresses several obstacles present in crosscounty comparative research (van Kesteren, 2007)

\section{ANALYSIS AND RESULTS}

Security is considered as a pillar that supports economic development and more particularly by encouraging domestic and foreign investor confidence (National Police Service, 2018). Therefore, the records of crimes committed are critical in identifying the crime trends in the country and the modalities that can be put in place to curb them. The data used in the study were drawn from the National Police Service reports on crime from 2014 to 2020.

\section{Crime Trends in Kenya between $2014-2020$}

The overall cases reported in 2014 were 69 376, which was considered a decrease of $3 \%$ as compared to the previous year where 71836 criminal cases were reported. (Kenya Police Service, 2015). The criminal cases reported in 2015 showed an increase of $4 \%$ as compared to 2014, which translated to 72490 cases (National Police Service, 2016). The criminal activities were characterized by terrorism, the inequity of resources, the proliferation of small arms and light weapons, drug and substance abuse, organized crimes, politics and ethnic driven rivalry, the sophistication of technology, and community boundary disputes (Kenya Police Service, 2015). The same criminal activities were reported in 2015 (National Police Service, 2016); in 2016 (National Police Service, 2017); in 2017 (National Police Service, 2018); in 2018 (National Police Service, 2019); in 2019 (National Police Service, 2020) and in 2020 (Table 1 below).

Table 1: Crime Trends in Kenya between 2014 - 2020

\begin{tabular}{llllllll}
\hline CRIMINAL OFFENSES & $\mathbf{2 0 1 4}$ & $\mathbf{2 0 1 5}$ & $\mathbf{2 0 1 6}$ & $\mathbf{2 0 1 7}$ & $\mathbf{2 0 1 8}$ & $\mathbf{2 0 1 9}$ & $\mathbf{2 0 2 0}$ \\
\hline Homicides & 2649 & 2648 & 2751 & 2774 & 2856 & 2971 & 3081 \\
Offences against Morality & 5184 & 6164 & 6228 & 5492 & 7233 & 8051 & 8834 \\
Other offences against Persons & 19911 & 21174 & 22295 & 22515 & 25049 & 27196 & 29122 \\
Robberies & 3011 & 2865 & 2697 & 2713 & 2935 & 2858 & 3027 \\
Break-ins & 5656 & 5591 & 5621 & 6131 & 5970 & 5976 & 5992 \\
Theft of Stock & 1848 & 1961 & 1918 & 2136 & 2077 & 1962 & 2262 \\
Stealing & 10042 & 9528 & 10361 & 11656 & 12845 & 13954 & 15204 \\
Theft by Servant & 2279 & 2184 & 2440 & 2632 & 2477 & 2226 & 2629 \\
Vehicles and other Thefts & 1239 & 1111 & 1355 & 1404 & 1370 & 1298 & 1159 \\
Dangerous Drugs & 4850 & 5225 & 6160 & 5565 & 8021 & 8011 & 8102 \\
Traffic Offenses & 100 & 120 & 139 & 69 & 213 & 341 & 352 \\
Criminal Damage & 3708 & 3983 & 4307 & 4262 & 4783 & 4852 & 4806
\end{tabular}

176 | This work is licensed under a Creative Commons Attribution 4.0 International License. 
East African Journal of Interdisciplinary Studies, Volume 3, Issue 1, 2021

Article DOI: https://doi.org/10.37284/eajis.3.1.387

\begin{tabular}{llllllll}
\hline CRIMINAL OFFENSES & $\mathbf{2 0 1 4}$ & $\mathbf{2 0 1 5}$ & $\mathbf{2 0 1 6}$ & $\mathbf{2 0 1 7}$ & $\mathbf{2 0 1 8}$ & $\mathbf{2 0 1 9}$ & $\mathbf{2 0 2 0}$ \\
\hline Economic Crimes & 3037 & 3244 & 3503 & 3695 & 4100 & 4786 & 4816 \\
Corruption & 144 & 79 & 92 & 75 & 119 & 130 & 142 \\
Offenses involving Police Officers & 47 & 71 & 57 & 86 & 174 & 77 & 103 \\
Offenses involving Tourists & 21 & 19 & 15 & 15 & 93 & 48 & 52 \\
Other Penal Code Offenses & 5650 & 6223 & 7074 & 6772 & 7953 & 8674 & 8725 \\
\hline TOTAL & $\mathbf{6 9 3 7 6}$ & $\mathbf{7 2 4 9 0}$ & $\mathbf{7 6 9 8 6}$ & $\mathbf{7 7 9 9 2}$ & $\mathbf{8 8 2 6 8}$ & $\mathbf{9 3 4 1 1}$ & $\mathbf{9 8 4 0 8}$ \\
\hline
\end{tabular}

Source: National Police Service

The reported crime incidents in 2016 increased by $6 \%$; from 72,496 cases reported in 2015 to a total of 76986 cases (National Police Service, 2017). In 2017 a total of 77922 cases of criminal activity were reported, which was an increase of $1.3 \%$ or 1006 cases from the previous year (National Police Service, 2018). In 2018, the total number of criminal cases reported was 88268 , which was an increase of about $13 \%$ from the previous year (National Police Service, 2019)

\section{Crime Trends based on Categories between $2014-2020$}

The decrements were noted in criminal activities such as robberies at (15\%); break-ins (12\%); homicides at $(8 \%)$; stealing $(12 \%)$; vehicle and other thefts (24\%); theft of stock $(6 \%)$ and other penal code offenses (10\%). The other criminal activities that were on increase included dangerous drugs (12\%); economic crimes (10\%); offenses against morality (8\%); offenses against other people (3\%), and criminal damages (3\%) (Kenya Police Service, 2015).

In 2015, the trend showed a decrement in crimes including cases such as theft of vehicle and motor vehicle parts (10\%); stealing $(5 \%)$; robberies $(5 \%)$; theft by a servant (5\%) and break-in cases (4\%). There were however increases in other criminal activities including offenses against morality (19\%); dangerous drugs (14\%); other penal code offenses $(10 \%)$; criminal damage $(7 \%)$; economic crimes (7\%); other offenses against people $(6 \%)$ and theft of stock (6\%) (National Police Service, 2016).

Some of the categories that indicated an increase in criminal activities in 2016 included vehicle and other theft (22\%); theft by servants (12\%); dangerous drugs $(11 \%)$; stealing $(9 \%)$; criminal Damage (8\%); economic crimes (8\%); other offences against people $(5 \%)$ and homicide $(4 \%)$.
However, decreases were noted in categories such as robberies $(6 \%)$; and theft of stock $(2 \%)$. Among individual criminal offenses, increases were noted in categories such as arson (20\%); housebreaking $(8 \%)$; obtaining by false pretense (7\%); defilement $(2 \%)$; dangerous drug (12\%); and drug trafficking (25\%) (National Police Service, 2017).

In terms of categories of criminal activity increments were noted in stealing $(12 \%)$, break-ins $(9 \%)$, theft of stock (11\%), offenses against people $(1 \%)$, theft by servants $(8 \%)$, economic crimes (5\%), vehicle and other thefts (4\%), offenses involving police officers $(51 \%)$ homicides $(1 \%)$ and robbery $(1 \%)$. There were also notable decreases in categories such as offenses against morality by $(12 \%)$, dangerous drugs by (10\%), under penal code offenses by (4\%), traffic offenses by (50\%) and corruption cases by (18\%) (National Police Service, 2018). In 2018, the increase in criminal activity based on categories included offenses against morality by $31.7 \%$; other penal code offenses by $17.4 \%$; criminal damage by $12.2 \%$; other offenses against people by $11.3 \%$; economic crimes by $11 \%$; stealing by $10.2 \%$ and robbery by $8.2 \%$. The decrease is based on categories included theft by servants $(5.9 \%)$; theft of stock $(2.8 \%)$, break-ins (2.6\%); and vehicles and other theft (2.4\%) (National Police Service, 2019).

\section{The Rate of Crime Index per 100,000 Persons}

The crime index per 100, 0000 persons in the 2014 year revealed that Taveta County was leading at 355 cases for every 100,000 persons, followed by Kirinyaga County with 312 cases; Mombasa County with 286 cases, Lamu County with 264 cases, and Nakuru County with 258 cases. The counties with the least crime index per 100,000 persons included Mandera county with 37 cases; Wajir County with 40 cases and Makueni County with 59 cases (Kenya Police Service, 2015). 
In 2015, Lamu County reported the highest crime rate in the of 485 cases per 100,000 persons, followed by Mombasa County with 340 cases; Taita Taveta County with 338 cases; Meru County with 311 cases; and Kiambu County with 294 cases. The least crime index per 100,000 people was recorded in Wajir County (31 cases); Mandera County (41 cases) and Garissa County (102 cases) (National Police Service, 2016).

Table 2: Highest Crime Index per 100000 Persons between 2014 - 2020

\begin{tabular}{llllllll}
\hline County & $\mathbf{2 0 2 0}$ & $\mathbf{2 0 1 9}$ & $\mathbf{2 0 1 8}$ & $\mathbf{2 0 1 7}$ & $\mathbf{2 0 1 6}$ & $\mathbf{2 0 1 5}$ & $\mathbf{2 0 1 4}$ \\
\hline Uasin Gishu & 376 & - & - & 306 & - & - & - \\
Isiolo & 395 & 379 & 358 & 267 & 354 & - & - \\
Kiambu & 402 & - & 427 & - & 370 & 294 & - \\
Meru & - & 403 & 419 & 278 & 377 & 311 & - \\
Nakuru & 416 & 432 & - & 313 & - & - & 258 \\
Lamu & - & - & 472 & - & 427 & 485 & 264 \\
Mombasa & - & 425 & - & 259 & 323 & 340 & 286 \\
Kirinyaga & - & - & 409 & - & - & - & 312 \\
Taita Taveta & - & - & - & - & - & 338 & 355 \\
Bomet & 53 & - & - & 57 & 101 & 41 & - \\
Garissa & & 53 & 78 & - & - & 102 & - \\
Makueni & 43 & - & - & 37 & - & - & 59 \\
Wajir & - & 37 & 65 & - & 33 & 31 & 40 \\
Mandera & 37 & 46 & 51 & 34 & 38 & - & 37 \\
\hline
\end{tabular}

In 2016, Lamu County retained its pole position, recording the highest crime index of 427 cases for every 10,000 persons. Meru County came in at the second position with 377 cases, Kiambu County had 370 cases; Isiolo County had 354 cases, and Mombasa County had 323 cases. The counties with low crime indices included Wajir County with 33 cases; Mandera County with 38 cases and Bomet County with 101 cases (National Police Service, 2017). In 2017, the Rift Valley region recorded the highest crime incidents in the country, totaling up to 19209 cases. In particular, Nakuru County had the highest number of cases totaling up to 313 cases, with Uasin Gishu County recording 2072 cases. The Eastern region was the second-highest in the country, recording a total of 14906 criminal cases. In particular, Méru County had the highest number of criminal cases totaling up to 5151 cases. The North-Eastern region, however, recorded the least number of criminal cases in the same year, which totaled up to 1323 cases (National Police Service, 2018).

In 2018, the highest crime rates were recorded in the Rift Valley region totaling up to 19802 cases. In particular, Nakuru County had the most cases recorded, totaling up to 4329 cases. The Eastern region was the second in terms of the criminal activities reported, with a total of 17062 cases. Lamu County reported the highest crime index per 10,000 persons of 472 cases; it was followed by Kiambu County by 427 cases; Meru County by 419 cases; Kirinyaga County by 409 cases and Isiolo County by 358 cases. The least crime index was reported in Mandera County 51 cases; Wajir County (65 cases); Garissa County (78 cases) and Turkana County (114 cases) (National Police Service, 2019).

\section{DISCUSSION OF FINDINGS}

The statistics provided by the NPS indicate that the crime trends in Kenya have been increasing gradually. The crime has been a function of various factors, notably amongst them include criminal activities were characterized by terrorism, the inequity of resources, the proliferation of small arms and light weapons, drug and substance abuse, organized crimes, politics and ethnic driven rivalry, the sophistication of technology, and community boundary disputes amongst others.

178 This work is licensed under a Creative Commons Attribution 4.0 International License. 


\section{Inter-tribal and Communal Conflict}

The intertribal and communal conflict was a significant cause of insecurity in 2014, characterized by ethnic incitements that led to serious conflicts reported in Isiolo, Wajir, and Mandera. The conflicts were caused by competition for natural resources such as land, pasture, and water, which led to skirmishes between the Degodia and Garreh communities. The conflicts were also attributed to the erosion of customary institutions, land demarcations, and ethnocentrism. A total of 45 people died while 30 others were seriously injured in a conflict that also leads to the destruction of property everything including touching of houses (Kenya Police Service, 2015). The 2015 report noted that tribal and communal conflicts among the communities in Turkana, Samburu and Marsabit counties cannot be divorced from cattle rustling and political incitements (National Police Service, 2016).

\section{Terrorism}

Terrorism was another source of insecurity in Kenya in 2014 with Al-Shabaab militants posing security threats with incidents of shootings and grenade attacks in major urban centers and remote places, affecting areas such as Nairobi, Mombasa, Mandera, Wajir, and Garissa. The militants targeted security officers, tourist destinations in the coastal area, churches, malls, and public service vehicles. In one incident on November 22nd, 2014, the militants attacked a bus headed to Nairobi from Mandela, shooting dead 28 non-Muslims. In another incident On December 2nd, 2014, the militants attacked 36 quarry workers living at Koromey in Mandera East. There were a total of 47 terrorist incidents reported in the same year, with 8 occurring in Nairobi, 12 in Garissa, 3 in Wajir, 12 in Mandera, 1 in Kwale, 3 in Lamu, 6 in Mombasa, and 2 in Marsabit (Kenya Police Service, 2015). There were fewer terrorist attacks in 2015. However, the attack by Al-Shabab militants at the Garissa University was the more notable terrorist activity during the year, leading to the loss of 149 lives. There were also other attacks reported in Lamu and Mandera counties. Cumulatively, 30 terror incidents were reported during the year as compared to 47 incidents that were reported in 2014, accounting for a 36\% drop. The police arrested 31 terror suspects. However, the number of deaths and injuries resulting from terrorist activities rose to 205 and 322 respectively, as compared to 173 deaths and 179 injuries that were important in 2014 (National Police Service, 2016).

\section{Figure 1: Reported terrorist incidents between 2014-202}

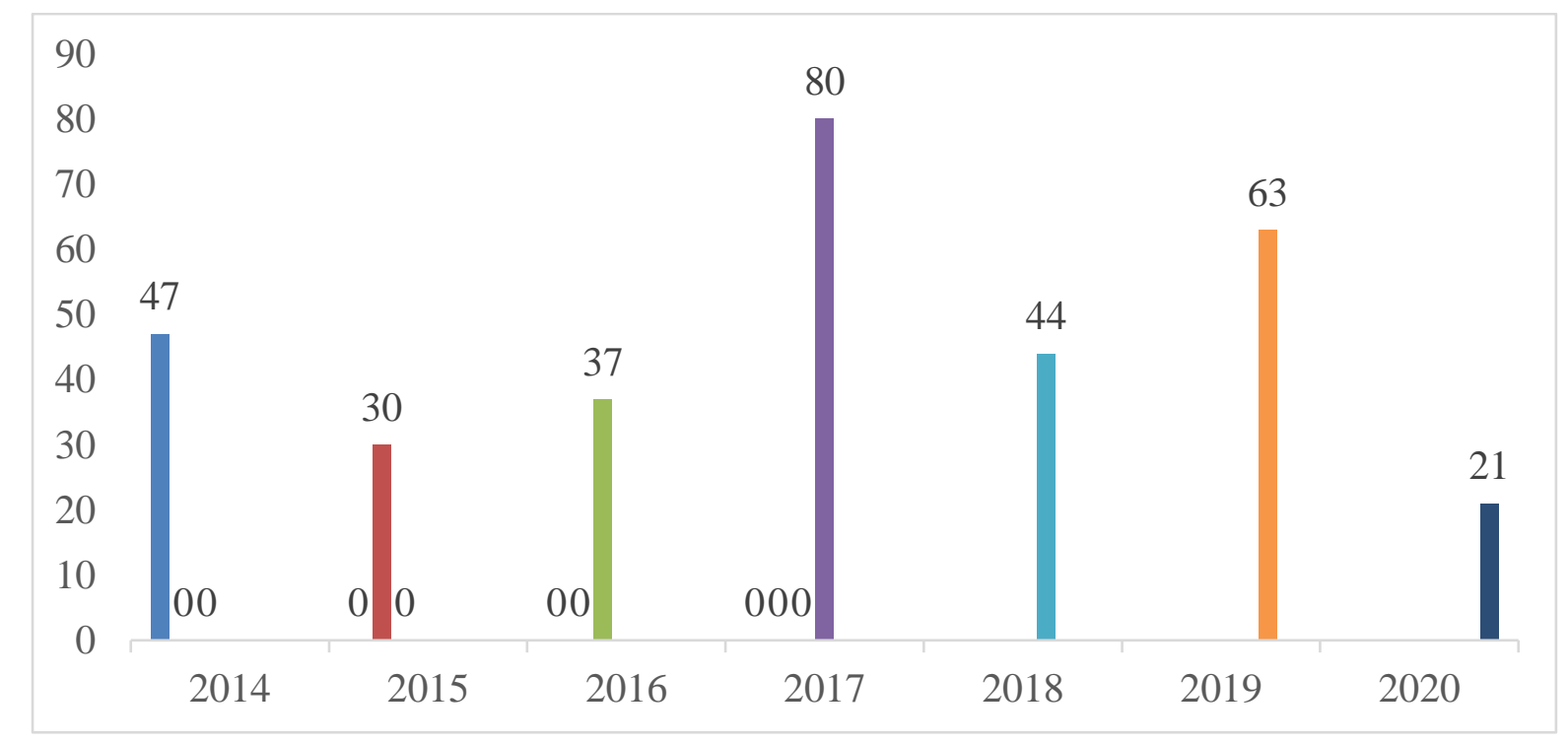

Terrorism remained a high cause of insecurity, regions in 2016. However, terrorist incidents particularly in the Coastal and North-Eastern

decreased by $28.8 \%$ in comparison to the previous 
year. A total of 20 suspected Al-Shabaab militants drawn from different nationalities such as Kenyans, Ugandans, Tanzanians, Somalis, and Americans were arrested during the year. There was a total of 37 terrorist cases were reported, which was a significant decline from the 52 cases that were reported in 2015. In the reported cases, 63 people were killed while 71 people sustained injuries (National Police Service, 2017). In 2017, they reported terrorism cases increased to 80 as compared to 37 reported in the previous year. A total of 82 people lost their lives during the terrorist activities while 118 were injured. The response to these attacks included the scaling up of Operation Linda Boni in the Boni Enclave Campaign to disrupt the terrorist networks that were operating in the Boni Forest. Additional security personnel was also deployed along with border counties and National Police Reserves who were well-versed with the local terrain and were also recruited (National Police Service, 2018). In 2018 there were 44 cases of terror attacks that were reported, which was a drastic decrease from the 80 that were recorded the previous year, translating into a $40 \%$ decrease. A total of 49 people lost their lives during the attacks while 41 people were injured. Mandera County reported $40 \%$ of the terror attack incidents (National Police Service, 2019).

\section{Radicalization of Youths at the Coastal Region}

The cause of insecurity in 2014 was associated with the radicalization of youths in Mombasa, Lamu, and Kwale counties. There was a various terrorist cell in the counties which aimed at radicalizing the youth as a way of expanding their base in the region and also push their agenda. The radicalization was challenging to police officers in terms of differentiating the suspected al-Shabaab members from the radicalized youths. Acting on intelligence the police conducted numerous raids at mosques such as Masjid Minna and Masjid Swaafa which led to the arrest of 274 suspects who were interrogated and arraigned in court (Kenya Police Service, 2015). Incidences of radicalization of youth in the coastal region were minimal in 2015, even though it remained a significant threat to security in the country (National Police Service, 2016).

\section{Mombasa Republican Council}

The activities by the Mombasa Republican Council were also associated with insecurity in 2014 and particularly in the coastal region. The group called for the secession of the coastal region from the rest of the country and was supported by a lot of locals, including local leaders. Members of the group post security threats by waging deadly attacks on unsuspecting members of the public and security installations. For instance, on November 2nd, they attacked the Maweni AP Camp in Malindi, damaging motor vehicles that were parked at the camp. Another group of armed youth attempted to attack the Nyali KDF barracks on the same day (Kenya Police Service, 2015).

\section{Cattle Rustling}

Insecurity in 2014 was also a function of cattle rustling activities among the Pokot, Turkana, and Samburu. Cattle rustling is attributed to the competition among these communities for scarce resources which include land, grazing fields, and water. There were 84 cases of cattle rustling reported in 2014 and 192 cases of stock theft reported. About 37 lives were lost during these criminal activities while 52 people were injured in the process (Kenya Police Service, 2015). In 2015, a new dimension to cattle rustling was observed whereby livestock was stolen for commercial reasons rather than the traditional cultural motivations. This made it increasingly difficult for authorities to recover the stolen livestock, as they were quickly disposed of and entered the consumer market. It was noted that cattle rustling was compounded by the instability in neighboring Somalia and South Sudan, which have contributed to the proliferation of small arms through the porous borders and the influx of illegal immigrants fleeing for safety. Illegal firearms played a significant role in intensifying cattle rustling incidents. The authorities found it increasingly difficult to track the stolen livestock due to the tough terrain in the semiarid regions (National Police Service, 2016). 
Figure 2: Reported Cattle Rustling Incidents between 2014 - 2020

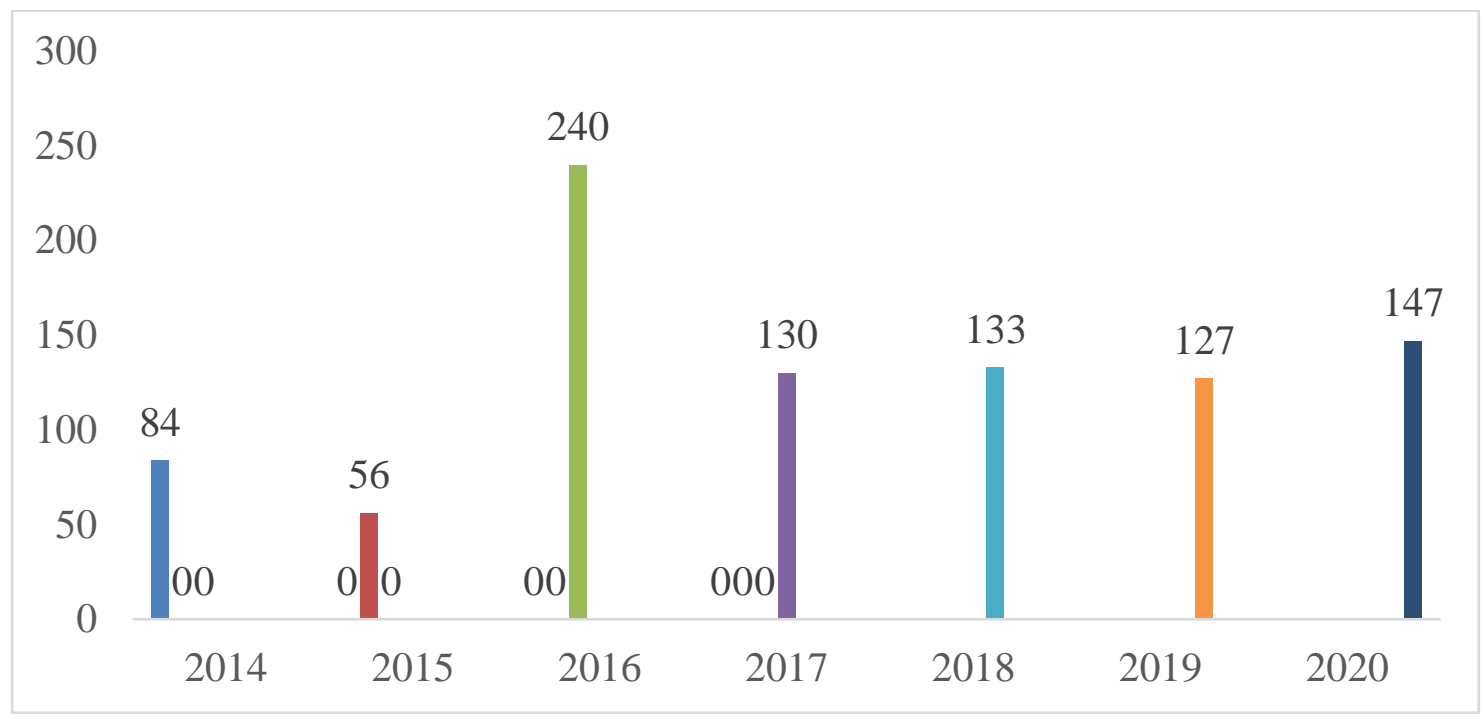

The government has instituted a raft of proactive strategies such as mopping up illegal firearms and joint operations by the security agencies to flush out cattle rustlers. Due to this, the reported cases for cattle rustling dropped in 2015 with 56 incidents being reported as compared to 84 this is the previous year, which accounted for a $33 \%$ drop (National Police Service, 2016). There was a total of 240 cases of cattle rustling and stock theft that was reported in 2016, with the Rift Valley region recording the highest cases of about $57 \%$ of the total cases that were reported. This was attributed to the pastoralist activities in the region as the main economic activities for most communities. A total of 30 people lost their lives in 2016 while 28 sustained injuries from cattle rustling activities. About 4547 livestock were stolen during the year while only 629 were recovered. There was a notable increase in cases of stock theft along the border between the Rift Valley and Nyanza region (National Police Service, 2017). In 2017, the reported cases for cattle rustling decreased to 130 cases, in which 4077 livestock were stolen and 786 livestock were recovered. 20 people were killed during the raids, whereas 17 people were injured. Most cases (83 cases) were reported in the Rift Valley region, while 28 cases were reported in the Nyanza region and 12 cases were reported in the Central region (National Police Service, 2018).

In 2018, cattle rustling continued to pose a threat to security in the northern region of the country leading to the displacement of families and fatalities. There were 133 cases of cattle rustling and stock theft that were reported in the year, which included the theft of 10726 livestock in which 5319 were recovered. The highest number of cattle rustling cases were in the Rift Valley region accounting for 99 , followed by the Nyanza region with 18 cases (National Police Service, 2019).

\section{The Proliferation of Small Arms and Light Weapons}

The proliferation of small arms and light weapons from neighboring countries such as Southern Sudan and Somalia was also reported as fueling internal strife and criminal activities in Kenya in 2014. Police recovered about 391 firearms and 5116 ammunitions from operations that were targeted at confiscating illegal firearms in the country (Kenya Police Service, 2015). In 2015 police confiscated a total of 332 illegal firearms and 3188 ammunitions (National Police Service, 2016). In 2018, police recovered 192 firearms and 1314 ammunition while 19 firearms were surrendered. Most of the firearms that were recovered were from Nairobi, Narok, and Kiambu counties (National Police Service, 2019).

\section{Drug Trafficking}

Drug trafficking is another criminal activity captured in the 2014 report, which noted that Kenya was a significant transit hub of drugs because of its strategic geographical location in the region and

181 This work is licensed under a Creative Commons Attribution 4.0 International License. 
continent. International drug syndicates from Europe, Asia, and West Africa used Kenya as their operational base. The report noted that drugs had become a menace in Kenyan society, largely affecting students and youth. On August 29th, 2014, the Kenyan government seized and destroyed a shipping vessel by the name MV ALNOOR, which was transporting heroin worth 1 billion through Kenya territorial waters (Kenya Police Service, 2015). Huge amounts of heroin from Iran and Pakistan and cocaine from Latin America transit through Kenya on the way to North America and Europe. Drug lords have established extensive local links, which has made it increasingly difficult for law enforcement authorities to combat the crime. For instance, the seizure of cocaine in the country is negligible and barely reflects the actual flow of the drug in and through the country (National Police Service, 2016).

In 2017, a total of 4510 cases of drugs and narcotic substance abuse were reported, and 4389 people were arrested for possessing and trafficking in narcotic drugs. Police impounded a total of 1402 kilograms of cannabis herbal, $17.35 \mathrm{~kg}$ of heroin, and $1.01 \mathrm{~kg}$ of cocaine (National Police Service, 2018). In 2018, a total of 3386 cases of drug and substance abuse were reported, which represented a $24.92 \%$ decrease from 2017. This included 3432 arrests made across the country with 3131 cases representing possession of drugs; 224 cases involving trafficking of drugs and 20 cases involving cultivating drugs (National Police Service, 2019).

\section{Cyber Crime}

In 2017, police reported a total of 423 cases of cybercrime, which had significantly increased as compared to 72 cases that were recorded in 2016. The increase in cybercrime was attributed to the reckless abuse of social media platforms during the electioneering period. The police noted a rise in computer-related fraudulent cases that targeted mobile Money Transfer services, banks, and SACCOs (National Police Service, 2018).

\section{Smuggling Contraband}

The smuggling of contraband goods was also another criminal activity that was reported in 2014.
Smuggling was noted as a rampant crime, especially along the Kenya-Somali border, Kenya-Tanzania border, and the Kenya-Uganda border. This translated into the flooding of the Kenyan market with contraband goods such as alcoholic stuff, food, and petroleum products, which have significantly eroded government revenue. In collaboration with other law enforcement officers, the police conducted crackdowns and seized goods such as sugar, alcohol, methanol/ethanol, Super match cigarettes, milk, rice, and Viking Cooking oil. A total of 427 arrests were made from the police raids (Kenya Police Service, 2015). In 2015 the police arrested a total of 170 people who were nabbed with contraband goods including cigarettes, alcoholic beverages, cosmetics, footwear, sugar, biscuits, powdered milk, clothing, radio sets, pesticides, rice, cooking oil, and mats (National Police Service, 2016).

\section{Violent Attacks on Law Enforcement Officers}

There was a marked increase in violent attacks on police officers in 2014. A total of 40 police officers were injured while 77 sustained injuries from such attacks. The most notable among many attacks in 2014 included the Kapedo attack against officers who had been deployed to respond to the insecurity tensions that were instigated by cattle rustling. The incident resulted in the death of 19 police officers with three others sustaining serious injuries (Kenya Police Service, 2015). The incidents of violent attacks on police officers decreased in 2015 as compared to 2014. A total of 28 police officers were killed on duty while 102 other officers were injured. Some of the notable deadly incidents were reported at Mandela and Lamu counties where suspected AlShabaab militants targeted police officers in transit using IEDs and landmines (National Police Service, 2016). A total of 70 police officers were killed in the line of duty in 2016. The highest number of attacks on police officers was recorded in the Rift Valley region. Other unfavorable environments for police to work in were reported in the coastal region occasioned by the activities of the Al-Shabab militant (National Police Service, 2017).

In 2017, 78 police officers were killed in the line of duty across the country. Most of these killings occurred in the North-Eastern region, accounting for 19 deaths of police officers and were related to 
ambushes by the Al-Shabaab militants in Garissa and Mandera counties. The attacks were also targeted on the police stations and the routes that are used by police during patrol. The Rift Valley region was also difficult terrain for the police to work in recording 18 deaths that were associated with their efforts to curb cattle rustling (National Police Service, 2018). In 2018, 65 police officers died in the course of duty, with $35 \%$ of these deaths being caused by terrorist activities in Garissa and Wajir counties. About 536 police officers were also injured in the line of duty from road accidents and terrorist attacks (National Police Service, 2019).

\section{Corruption}

In 2014 and 2015, the Ethics and Anti-Corruption Commission increased its surveillance and apprehension of police officers who were engaged in corrupt practices. Some of the measures that were enacted to fight corruption within the National Police service included the enhancement of management and supervision of officers; and the sensitization of officers on corruption issues through weekly lectures (National Police Service, 2016).

\section{Illegal Immigrants}

The inflow of illegal immigrants into the country was noted as a significant challenge to national security in 2015. Most illegal immigrants are unaccounted for and enter the country with ulterior motives, including dealing in illegal firearms and perpetrating terrorist activities. The police crackdown on illegal immigrants led to the arrest of 1878 people, with $58 \%$ of the illegal immigrants being Ethiopians (National Police Service, 2016). There was an increase in the number of aliens and illegal immigrants who were arrested in Nairobi and Busia by the police. Reported hotspots for illegal immigrant smuggling included Mombasa and Eastleigh Nairobi, where women and children are trafficked for prostitution, and forced labor (National Police Service, 2017). In 2017, a total of 915 aliens and undocumented immigrants were arrested by the police across the country. Most of them were arrested in Nairobi and Busia and included women and children who were trafficked for forced labor and prostitution (National Police Service, 2018). In 2018, police arrested a total of
2173 aliens and undocumented immigrants, with $40 \%$ of them coming from Ethiopia and Tanzania (National Police Service, 2019)

\section{Political Activities}

Political activities contributed to crime incidents in 2015 , in which case politicians used the media to propagate insightful utterances. In particular, social media was used to spread hate messages; other mediums included the use of leaflets and phone text messages. The Director of Criminal Investigations (DCI), the Office of the Director of Public Prosecutions (ODPP), and the National Cohesion and Integration Commission (NCIC) apprehended and charged politicians who were making insightful remarks and spreading messages (National Police Service, 2016). The general election environment of 2017 was another key security issue in the country, characterized by contentious campaigns and repeat presidential elections. A total of 23 civilian deaths were reported in 12 counties and 28 injuries related to the election activities. The tribal nature of the presidential race politics was a key motivator of the violence associated with the electioneering period (National Police Service, 2018).

\section{School Unrest}

School unrest is another cause of criminal activities that draw the attention of security agencies in the country. School unrest involves strikes, agitations, and/or boycotts of learning activities by students in schools, colleges, and other educational institutions. School unrest does not just threaten the continuity of the education system but often results in arson, violence, and the destruction of educational facilities. In 2017, there were about 235 cases of school unrest, which was considered a decrease compared to the 300 cases that were reported in 2016. A total of 47 schools were affected with 92 dormitories being touched down, while 10 students died and 82 others were injured. The police arrested 108 students suspected of having masterminded the unrest, including 24 other people who were subsequently prosecuted (National Police Service, 2018). In 2018, 168 educational institutions were affected by school unrest, indicating a decrease of $23 \%$ as compared to the previous year in which 163 institutions were affected (National Police Service, 2019). 


\section{Illicit brew}

The illicit brew is also considered drug trafficking and has proved to be a significant social problem that has generated attention by the government. The illicit brew has resulted in many deaths and incapacitation, undercutting the productivity of many youths, making them unfit for gainful employment. A presidential directive on July 3rd, 2015 necessitated a Nationwide Crackdown on illicit brew and second-generation alcohol, leading to the arrests of 17233 manufacturers, distributors, retailers, and consumers. Besides, a total of $15,951,301$ liters of illicit brew were netted by the authorities. However, the crackdown on the manufacture, storage, sale, and consumption of the illicit brews was significantly hampered by various court orders that were issued against the law enforcement officers (National Police Service, 2016). In 2018, police confiscated a total of 194341 liters of illicit brew, which was significantly higher as compared to the 175997 that were netted the previous year (National Police Service, 2019).

\section{CONCLUSION}

The reporting of criminal activities in Kenya between $2014-2020$ has generally been increasing gradually. This indicates that the increase in the report of criminal activities has not translated into the enactment of measures to curb crime. There is, therefore, a need for the government to come up or strengthen the measures that have been put in place to curb crime associated with inter-tribal and communal conflicts, terrorism, cattle rustling, corruption, attacks against police officers, illegal immigrants, school unrest, political activities, cybercrime, smuggling, drug trafficking, the radicalization of youth and the proliferation of small arms.

\section{RECOMMENDATIONS}

The police could capitalize on the connected intelligence through community policing. Communal intervention through local peace committees can go a long way in forging peaceful coexistence and minimizing tensions between antagonistic communities. The police should also expedite the investigation and prosecution of cases.
Police involved in corrupt activities should be apprehended and prosecuted.

The government should come up with effective frameworks for boosting security at all entry and exit points at the border, an exercise that should involve all the security agencies in the country. It is also necessary for the government to invest in the expansion of the police population ratio to reach the UN stipulated standard of 1 policeman to 450 citizens. Besides the police should be equipped with modern investigation tools such as forensic Laboratories to have them expedite their investigation tasks. The acquisition of equipment such as night vision goggles, armored personnel carriers and bulletproof vests to be used in police operations will also make their work of protecting and providing security more efficient.

\section{REFERENCES}

Baumer, E. P., \& Lauritsen, J. L. (2010). Reporting crime to the police, 1973-2005: a multivariate analysis of long-term trends in the National Crime Survey (NCS) and National Crime Victimization Survey (NCVS). Criminology, 48 (1), 131-185.

Bennett, R. R., \& Wiegand, R. B. (1994). Observations on crime reporting in a developing nation. Criminology, 32(1), 135-148.

Block, P. (1993). Stewardship: Choosing service over self-interest. Berrett-Koehler Publishers.

Boateng, F. D. (2018). Crime reporting behavior: do attitudes toward the police matter? Journal of interpersonal violence, 33(18), 2891-2916.

Bouten, E., Goudriaan, H., Nieuwbeerta, P., Benítez, M. J., \& Medina, J. J. (2003). Victimación delictiva en 17 países industrializados. Revista Española de Investigación Criminológica, 1, 1-21.

Deci, E. L., Koestner, R., \& Ryan, R. M. (1999). A meta-analytic review of experiments examining the effects of extrinsic rewards on intrinsic motivation. Psychological bulletin, 125(6), 627.

Felson, R. B., Messner, S. F., Hoskin, A. W., \& Deane, G. (2002). Reasons for reporting and not

184 | This work is licensed under a Creative Commons Attribution 4.0 International License. 
reporting domestic violence to the police. Criminology, 40(3), 617-648.

Gottfredson, M. R., \& Hindelang, M. J. (1979). Theory and research in the sociology of law. American Sociological Review, 27-37.

Gutierrez, C. M., \& Kirk, D. S. (2017). Silence speaks: The relationship between immigration and the underreporting of crime. Crime \& Delinquency, 63(8), 926-950.

Guzy, N., \& Hirtenlehner, H. (2015). Trust in the German police: determinants and consequences for reporting behavior. In Trust and legitimacy in criminal justice (pp. 203-229). Springer, Cham.

Kenya Police Service. (2015). Annual Crime Report 2014. Retrieved from https://www.nationalpolic e.go.ke/crime-statistics.html

Kenya Police. (2007, Aug 4th). Kenyapolice.go.ke. Retrieved Oct 19, 2007, from crime statistics.asp.

Kury, H., Teske Jr, R. H., \& Würger, M. (1999). Reporting of crime to the police in the Federal Republic of Germany: A comparison of the old and the new lands. Justice quarterly, 16(1), 123151.

National Police Service. (2016). Crime Situation Report. Retrieved from https://www.nationalpol ice.go.ke/crime-statistics.html

National Police Service. (2017). Annual Crime Report 2016. Retrieved from https://www.natio nalpolice.go.ke/crime statistics.html

National Police Service. (2018). Crime Situation Report. Retrieved from https://www.nationalpol ice.go.ke/crime-statistics.html

National Police Service. (2019). Annual Crime Report 2018. Retrieved from https://www.nationalpolice.go.ke/crimestatistics.html

Pino, N. W., \& Meier, R. F. (1999). Gender differences in rape reporting. Sex roles, $40(11)$, 979-990.
Skogan, W. G. (1984). Reporting crimes to the police: The status of world research. Journal of research in crime and delinquency, 21(2), 113137.

Sparks, R. F., Genn, H. G., \& Dodd, D. J. (1977). Surveying victims: A study of the measurement of criminal victimization, perceptions of crime, and attitudes to criminal justice. New York: Wiley.

Tseloni, A., Wittebrood, K., Farrell, G., \& Pease, K. (2004). Burglary victimization in England and Wales, the United States and the Netherlands: A cross-national comparative test of routine activities and lifestyle theories. British Journal of Criminology, 44(1), 66-91.

United Nations. (2013). Report of the Monitoring Group on Somalia and Eritrea pursuant to Security Council Resolution 2060 (2012): Somalia. UN doc.S/2013/413, July $13^{\text {th }}$

van de Weijer, S., Leukfeldt, R., \& Van der Zee, S. (2020). Reporting cybercrime victimization: determinants, motives, and previous experiences. Policing: An International Journal.

Van Kesteren, J. N. (2007). Integrated Database from the International Crime Victims Survey (ICVS). 